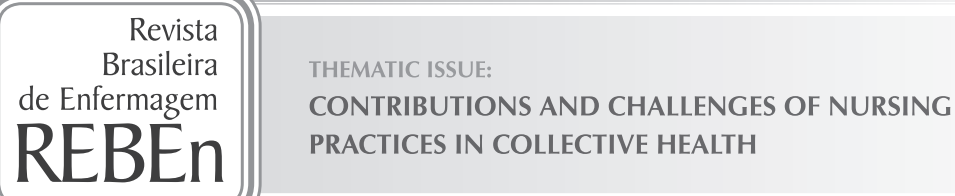

\title{
People living on the street from the health point of view
}

\author{
Pessoas que vivenciam situação de rua sob o olhar da saúde \\ Personas que viven situación de calle bajo la mirada de la salud
}

\author{
Paula Hino', Jaqueline de Oliveira Santos", Anderson da Silva Rosa' \\ ' Universidade Federal de São Paulo, Paulista Nursing School. São Paulo, Brazil. \\ "Universidade Paulista, Departament of Nursing. São Paulo, Brazil.
}

\begin{abstract}
How to cite this article:
Hino P, Santos JO, Rosa AS. People living on the street from the health point of view. Rev Bras Enferm [Internet]. 2018;71(Suppl 1):684-92. [Thematic Issue: Contributions and challenges of nursing practices in collective health] DOI: http://dx.doi.org/10.1590/0034-7167-2017-0547
\end{abstract}

Submission: 08-10-2017_Approval: 11-18-2017

\section{ABSTRACT}

Objective: To know the Brazilian scientific production of the last ten years (2007 to 2016) about people who experience street situations under the health gaze. Method: Integrative literature review using the descriptors: street people, health policy and public health. We analyzed 21 articles available in the Virtual Health Library. Results: Four categories of analysis emerged. There was an increase in the frequency of published work on the subject, showing that the experience of living on the street makes people vulnerable to various diseases and health problems and, in addition, increases the difficulties of access to health services. Conclusion: There was an increase in the discussion of this topic due to the increase in the number of published studies. Despite the existence of public health policies directed to this social group, much still needs to be done to guarantee the health of this population.

Descriptors: People in a Street Situation; Public health; Vulnerable Populations; Public Health Nursing; Needs and Demands of Health Services.

\section{RESUMO}

Objetivo: Conhecer a produção científica brasileira dos últimos dez anos (2007 a 2016) sobre as pessoas que vivenciam situação de rua sob o olhar da saúde. Método: Revisão integrativa da literatura utilizando os descritores: pessoas em situação de rua, política de saúde e saúde pública. Foram analisados 21 artigos disponíveis na Biblioteca Virtual em Saúde. Resultados: Emergiram quatro categorias de análise. Constatou-se um aumento na frequência de trabalhos publicados sobre a temática, evidenciando que a experiência de viver na rua torna as pessoas vulneráveis a diversas doenças e agravos à saúde e, além disso, aumenta as dificuldades de acesso aos serviços de saúde. Conclusão: Houve ampliação da discussão dessa temática em função do aumento do número de estudos publicados. Apesar da existência das políticas públicas de saúde direcionadas a esse grupo social, muito ainda deve ser feito para a garantia da saúde dessa população.

Descritores: Pessoas em Situação de Rua; Saúde Pública; Populações Vulneráveis; Enfermagem em Saúde Pública; Necessidades e Demandas de Serviços de Saúde.

\section{RESUMEN}

Objetivo: Conocer la producción científica brasileña de los últimos diez años (2007 a 2016) sobre las personas que vivencian situación de calle bajo la mirada de la salud. Método: Revisión integrativa de la literatura utilizando los descriptores: personas en situación de calle, política de salud y salud pública. Se analizaron 21 artículos disponibles en la Biblioteca Virtual en Salud. Resultados: emergieron cuatro categorías de análisis. Se constató un aumento en la frecuencia de trabajos publicados sobre la temática, evidenciando que la experiencia de vivir en la calle hace a las personas vulnerables a diversas enfermedades y agravios a la salud y además aumenta las dificultades de acceso a los servicios de salud. Conclusión: Hubo ampliación de la discusión de esta temática en función del aumento del número de estudios publicados. A pesar de la existencia de las políticas públicas de salud dirigidas a ese grupo social, mucho aún debe ser hecho para la garantía de la salud de esa población.

Descriptores: Personas en Situación de Calle; Salud Pública; Poblaciones Vulnerables; Enfermería en Salud Pública; Necesidades y Demandas de Servicios de Salud.

\section{CORRESPONDING AUTHOR Paula Hino_E-mail: paula.hino@unifesp.br}




\section{INTRODUCTION}

The population living on the street has been increasing for several reasons, such as: poverty, structural unemployment, migration, chemical dependency, family conflicts, among others. This population includes people excluded from the conventional structures of society, people who have less than what is necessary to meet the basic needs of the human being, who live in the line of indigence or absolute poverty, who live in extreme poverty and their survival is often compromised ${ }^{(1)}$.

The existence of the population living on the street is a social phenomenon that is assuming new expressions in contemporary societies, particularly in urban centers. This social group that is marginalized by society has housing as public or philanthropic places and shelters, and also experiences working situations, living conditions and precarious social insertions. The lack of conventional housing is not the only problem experienced by the people who belong to this group, this situation affects the commitment of other important socioeconomic factors, such as identity, security, physical and emotional well-being, feelings of belonging and roots $^{(2)}$.

There is little homogeneity in this group, since the main differences between its components are related to life trajectories, length of stay on the street, survival strategies adopted, gender relations and dynamics of the inhabited territory itself $f^{(3)}$. These excluded and marginalized groups seek the central regions of the cities to live in because these places generally offer greater facilities for living on the streets, such as commercial areas or areas with a greater concentration of services, the great circulation of people and the few residences ${ }^{(2)}$.

People living on the street sometimes do not have precise chronological time of staying on the street, but the going to the street is almost always marked by an unforgettable event for those who lived it, which is rarely commented, even with people of conviviality. Taking as a parameter the length of stay on the street, the relationship with this context of life and the family ties, the population living in a street situation can be classified into three different situations: staying on the street (circumstantially), being on the street (recently) and being on the street (permanently) $)^{(4)}$.

In the past, there was a speech of invisibility and absence of the State in the problematic of the population living in the street situation. Currently, there are several public policies focused on this segment. However, it is worth questioning the commitment of the State to implement the actions that are assured by laws and guidelines. The main Brazilian legislation focused on the health care of this population is the National Policy for the Population Living on the Street (PNPSR), created in 2009. In addition to the principles of universality, equality and equity, this Policy is based on respect for dignity of the human person, the right to family and community coexistence, valorization and respect for life and citizenship, humanized care and respect for social conditions and differences of origin, race, age, nationality, gender, sexual and religious orientation, with special attention to people with disabilities ${ }^{(5)}$.

According to the PNPSR, the population living in a street situation is defined as a population group that has in common extreme poverty, broken or fragile family ties, and the lack of regular conventional housing, using public places and areas degraded as a place of living and livelihood, temporarily or permanently, as well as the host units, for temporary overnight or as temporary housing ${ }^{(5)}$.

In addition, the Ordinance $\mathrm{n}^{\circ} .122$, published in 2011 by the Ministry of Health, also contributed to increase the access of the people in the street to the health services and, thus, to better attend to the health needs of this population. The aforementioned Ordinance was important because it defined the guidelines for the operation and organization of the Office on the Street team (OSt), a structure that integrates the basic care of the Psychosocial Care Network and develops Basic Health Care actions according to the foundations and guidelines defined in the National Primary Health Care Policy. According to this Ordinance, OSt must be multiprofessional and deal with the different health problems and needs of the street population, including active search activities and care for users of alcohol, crack and other drugs ${ }^{(6)}$.

\section{OBJECTIVE}

Due to the increase in the number of people living on the streets and the recent structuring of guidelines, services, teams and actions aimed at the health care of this population, this study aimed to know the Brazilian scientific production of the last ten years (2007 to 2016) about people who experience street situation from the health point of view.

\section{METHOD}

A bibliographical review was carried out, applying the integrative analysis on the aspects related to the health of people living in the street. For the development of this study, the six stages that compose the elaboration of an integrative review were: 1) establishment of the research question; 2) search in the literature; 3) categorization of studies; 4) evaluation of included studies; 5 ) interpretation of results; and 6) synthesis of knowledge(7).

The guiding question of this research was: "What are the axes addressed by the national scientific literature regarding the health of people living on the street?" To answer this question, a bibliographic survey was carried out in the Virtual Health Library (VHL), using the descriptors people in street situation, health policy and public health. Data collection took place in November 2016.

The criteria used for the selection of articles were: scientific articles available in full on the internet, written in Portuguese, published between 2007 and 2016. Articles related to children, adolescents and the elderly were excluded (due to their specificities), the repeated works and those that did not serve the purposes of this research. 


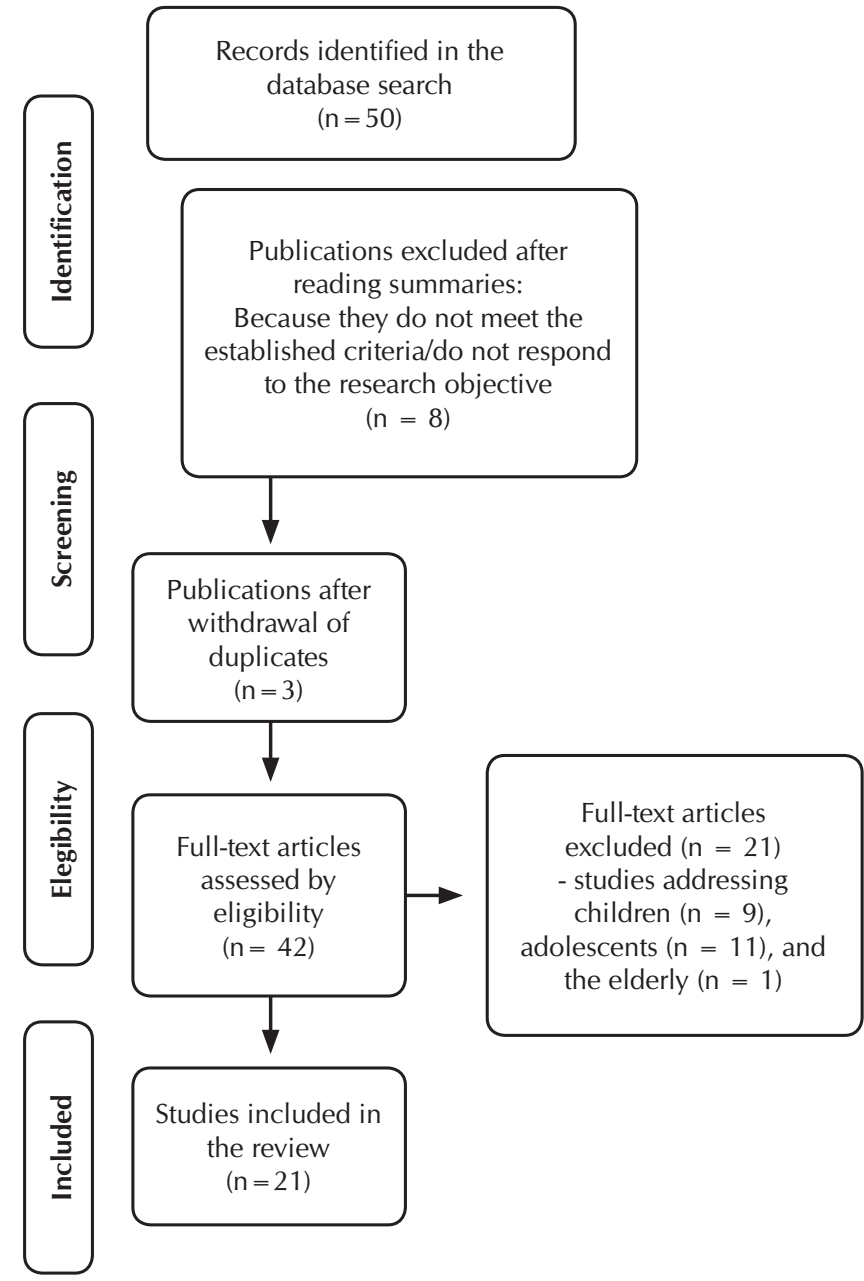

Figure 1 - Sample selection flowchart according to the Preferred Reporting Items for Systematic Reviews and Meta-Analyzes (PRISMA)
Initially, the studies identified using the three descriptors were selected by reading the title. In this stage, only the articles that addressed the theme of this study and those that were published during the defined period were selected; and repeated articles were excluded. Subsequently, the abstracts of the works were read, excluding those that were not fully available on the Internet and those that addressed children, adolescents and the elderly. Thus, 21 scientific articles were analyzed in this study. The flow chart presented below outlines the course of the bibliographic survey adopted by the researchers for the elaboration of this research. (Figure 1)

For the analysis of the bibliographical material, two researchers carried out the reading of the articles in their entirety and, from that moment, a form was elaborated that contemplated information regarding the year of publication, title, periodical, objective and type of study.

\section{RESULTS}

A total of 21 scientific papers published in national journals were analyzed and related to the health of people living in the street. The table below shows the empirical material used to carry out this research, second year of publication, title, periodical, objective and type of study.

Through the analysis of the Brazilian scientific production on the aspects related to the health of people living in the street, four categories of analysis emerged: (1) Access to social and health facilities; (2) Diseases and health problems; (3) Health practices and policies; and (4) Office on the street.

Chart 1 - Distribution of scientific articles according to year of publication, title, periodical and objective, 2016

\begin{tabular}{|c|l|l|l|l|}
\hline Year & \multicolumn{1}{|c|}{ Title } & Journal & \multicolumn{1}{c|}{ Objective } \\
\hline 2010 & $\begin{array}{l}\text { The Family Health Strategy focused on } \\
\text { access equity and targeted at the homeless } \\
\text { population living in large urban centers }\end{array}$ & $\begin{array}{l}\text { Saúde e } \\
\text { Sociedade }\end{array}$ & $\begin{array}{l}\text { To describe the experience of implementing the } \\
\text { Family Health Strategy for the health care of the } \\
\text { population living in a street situation in the city of } \\
\text { São Paulo }\end{array}$ & $\begin{array}{l}\text { Experience } \\
\text { report }\end{array}$ \\
\hline 2011 & $\begin{array}{l}\text { Adultos em situação de rua: acesso aos } \\
\text { serviços de saúde e constante busca } \\
\text { pela ressocialização. (Freely translated: } \\
\text { Adults in street situations: access to } \\
\text { health services and constant search for } \\
\text { resocialization) }\end{array}$ & $\begin{array}{l}\text { Revista Contexto } \\
\text { Saúde }\end{array}$ & $\begin{array}{l}\text { To analyze the problems experienced by adults } \\
\text { living on the streets }\end{array}$ & $\begin{array}{l}\text { Bibliographic } \\
\text { review }\end{array}$ \\
\hline Health care and diagnosis as a threat: \\
public policies and homeless people
\end{tabular}


Chart 1 (concluded)

\begin{tabular}{|c|c|c|c|c|}
\hline Year & Title & Journal & Objective & Type of study \\
\hline 2014 & $\begin{array}{l}\text { Access, equity and social cohesion: } \\
\text { evaluation of intersectoral strategies for } \\
\text { people experiencing homelessness }\end{array}$ & $\begin{array}{l}\text { Revista da Escola } \\
\text { de Enfermagem } \\
\text { da USP }\end{array}$ & $\begin{array}{l}\text { To understand and evaluate the intersectoral } \\
\text { assistance work on the insertion and flow of people } \\
\text { on the street with severe mental disorder }\end{array}$ & Case study \\
\hline 2014 & $\begin{array}{l}\text { Prevalence of Syphilis and associated } \\
\text { factors in homeless people of Sao Paulo, } \\
\text { Brazil, using a Rapid Test }\end{array}$ & $\begin{array}{l}\text { Revista } \\
\text { Brasileira de } \\
\text { Epidemiologia }\end{array}$ & $\begin{array}{l}\text { To describe behaviors, attitudes and risk } \\
\text { practices for STDs, to estimate the prevalence of } \\
\text { syphilis in people living on the streets }\end{array}$ & $\begin{array}{l}\text { Cross-sectional } \\
\text { study }\end{array}$ \\
\hline 2014 & $\begin{array}{l}\text { Support as care for existential territory: } \\
\text { Primary Care and the street }\end{array}$ & $\begin{array}{l}\text { Interface- } \\
\text { Comunicação, } \\
\text { Saúde e } \\
\text { Educação }\end{array}$ & $\begin{array}{l}\text { To demonstrate a connection between the } \\
\text { following practices: support, basic care team } \\
\text { and care for the population living on the streets } \\
\text { under the SUS }\end{array}$ & $\begin{array}{l}\text { Reflection } \\
\text { paper }\end{array}$ \\
\hline 2014 & $\begin{array}{l}\text { Population in vulnerability, inter- } \\
\text { sector cooperation and citizenship: } \\
\text { interconnecting knowledge and actions }\end{array}$ & $\begin{array}{l}\text { Saúde e } \\
\text { Sociedade }\end{array}$ & $\begin{array}{l}\text { To discuss the experience of holding an event } \\
\text { that discussed the causality and complexity of } \\
\text { the street population }\end{array}$ & $\begin{array}{l}\text { Experience } \\
\text { report }\end{array}$ \\
\hline 2014 & $\begin{array}{l}\text { Health practices by teams from Street } \\
\text { Outreach Offices }\end{array}$ & $\begin{array}{l}\text { Cadernos de } \\
\text { Saúde Pública }\end{array}$ & $\begin{array}{l}\text { To know the practices of health carried out in } \\
\text { the daily life of the teams of Office on the street }\end{array}$ & $\begin{array}{l}\text { Exploratory } \\
\text { study }\end{array}$ \\
\hline 2014 & $\begin{array}{l}\text { The street has a magnet, I think it is } \\
\text { freedom: power, suffering, and life } \\
\text { strategies among homeless persons in the } \\
\text { city of Santos, São Paulo, Brazil }\end{array}$ & $\begin{array}{l}\text { Saúde e } \\
\text { Sociedade }\end{array}$ & $\begin{array}{l}\text { To investigate people in a street situation, } \\
\text { analyzing their memories, affections and plans } \\
\text { for the future. }\end{array}$ & $\begin{array}{l}\text { Exploratory } \\
\text { study }\end{array}$ \\
\hline 2015 & $\begin{array}{l}\text { Violence in the lives of homeless } \\
\text { women in the city of São Paulo, Brazil }\end{array}$ & $\begin{array}{l}\text { Interface- } \\
\text { Comunicação, } \\
\text { Saúde, } \\
\text { Educação }\end{array}$ & $\begin{array}{l}\text { To bring to the reflection situations of violence } \\
\text { in the life of women in street condition in the } \\
\text { city of São Paulo }\end{array}$ & $\begin{array}{l}\text { Cartography } \\
\text { study }\end{array}$ \\
\hline 2015 & $\begin{array}{l}\text { Policies for the Adult Population Living } \\
\text { on the Streets: Questions for Debate }\end{array}$ & Katálysis & $\begin{array}{l}\text { To analyze the specificities of the social question } \\
\text { in Brazil, focusing on the conditions of the adult } \\
\text { population in the street situation }\end{array}$ & $\begin{array}{l}\text { Qualitative } \\
\text { research }\end{array}$ \\
\hline 2015 & $\begin{array}{l}\text { Street Outreach Offices: visibility, } \\
\text { invisibility, and enhanced visibility }\end{array}$ & $\begin{array}{l}\text { Cadernos de } \\
\text { Saúde Pública }\end{array}$ & $\begin{array}{l}\text { To reflect on care for the population living on } \\
\text { the street }\end{array}$ & $\begin{array}{l}\text { Participant } \\
\text { observation }\end{array}$ \\
\hline 2015 & $\begin{array}{l}\text { Care practices and homeless } \\
\text { population: the street clinic case }\end{array}$ & Saúde e Debate & $\begin{array}{l}\text { To characterize how the team at the Victor } \\
\text { Valla Family Clinic Rua develops its health care } \\
\text { practices }\end{array}$ & Case study \\
\hline 2015 & $\begin{array}{l}\text { Health social inequality of the homeless } \\
\text { in the city of São Paulo }\end{array}$ & $\begin{array}{l}\text { Saúde e } \\
\text { Sociedade }\end{array}$ & $\begin{array}{l}\text { To describe the socio-demographic } \\
\text { characteristics, health status and access to } \\
\text { services in the street population }\end{array}$ & $\begin{array}{l}\text { Household } \\
\text { surveys }\end{array}$ \\
\hline 2016 & $\begin{array}{l}\text { Tool and ideological knowledge in } \\
\text { Street Outreach Office working process }\end{array}$ & $\begin{array}{l}\text { Revista da Escola } \\
\text { de Enfermagem } \\
\text { da USP }\end{array}$ & $\begin{array}{l}\text { Identify the ideological and instrumental } \\
\text { knowledge that subsidizes the work process of } \\
\text { the Office on the street }\end{array}$ & $\begin{array}{l}\text { Qualitative and } \\
\text { exploratory } \\
\text { research }\end{array}$ \\
\hline 2016 & $\begin{array}{l}\text { Working in the street clinic: use of } \\
\text { IRAMUTEQ software on the support of } \\
\text { qualitative research }\end{array}$ & $\begin{array}{l}\text { Escola Anna } \\
\text { Nery }\end{array}$ & $\begin{array}{l}\text { To know the most frequent vocabulary in the report } \\
\text { of a typical week of work experienced by the } \\
\text { professionals of the Teams of the Office on the street }\end{array}$ & $\begin{array}{l}\text { Qualitative and } \\
\text { exploratory } \\
\text { research }\end{array}$ \\
\hline 2016 & $\begin{array}{l}\text { Homeless people's right to health: } \\
\text { reflections on the problems and } \\
\text { components }\end{array}$ & $\begin{array}{l}\text { Ciência \& Saúde } \\
\text { Coletiva }\end{array}$ & $\begin{array}{l}\text { To identify, in the literature, what is related to the } \\
\text { characterization of the street population, their } \\
\text { needs and the policies developed for the care }\end{array}$ & $\begin{array}{l}\text { Integrative } \\
\text { review }\end{array}$ \\
\hline 2016 & $\begin{array}{l}\text { Experience of health professionals in } \\
\text { care of the homeless population with } \\
\text { tuberculosis }\end{array}$ & $\begin{array}{l}\text { Revista da Escola } \\
\text { de Enfermagem } \\
\text { da USP }\end{array}$ & $\begin{array}{l}\text { To analyze the speeches of the health } \\
\text { professionals of the Practice in the Street in } \\
\text { relation to the care to the person in street } \\
\text { situation with tuberculosis }\end{array}$ & $\begin{array}{l}\text { Qualitative } \\
\text { research }\end{array}$ \\
\hline 2016 & $\begin{array}{l}\text { From the stigmatizing disease to } \\
\text { resignification of living on the streets }\end{array}$ & $\begin{array}{l}\text { Revista } \\
\text { Eletrônica de } \\
\text { Enfermagem }\end{array}$ & $\begin{array}{l}\text { To understand the existing relationships in the } \\
\text { process of resignification of life on the street from } \\
\text { the diagnosis of a socially stigmatizing disease }\end{array}$ & $\begin{array}{l}\text { Qualitative } \\
\text { research }\end{array}$ \\
\hline
\end{tabular}




\section{DISCUSSION}

The first category, "Access to health services", highlighted the difficulties faced by street dwellers for their inclusion in the Brazilian health system. Different reasons have been cited that impede or delay the demand for a health service, such as prejudice and discrimination related to hygiene conditions, which is hampered by the use of dirty clothing, lack of bathing, foul smell, and the lack of documentation for identification and registration of the user and the long waiting period for the service ${ }^{(8-11)}$.

People who live in a street situation are also victims of prejudice when they seek a health service and are faced with the unpreparedness and inability of health professionals to perform qualified listening and the reception of the health demands and needs of this population, as well as when the hygienic actions that occur in public spaces and that disregard the dignity of life and human rights ${ }^{(12)}$.

The fragility of this specific group was also cited in a study developed in the city of São Paulo-SP involving people who used shelters. The participants of this research reported that they suffered discrimination by society not only due to the precarious hygiene conditions, but also by the physical and mental incapacity of some homeless people and by racial prejudice ${ }^{(9)}$.

Thus, the health of these people is even more compromised because they violate the principles of universality of access to health services, equity in access to health services and services, and integral care.

By using the public spaces as places of dwelling, a new phase of the life of these people begins, a phase that is different from the previous way of life. The attempt to understand the narratives of experiences of this population is a challenge because, while some individuals report the suffering of living on the street, the yearning for transformation of reality and return to domestic life, others say that they have become accustomed to the daily life on the street and wish to continue ${ }^{(10)}$.

Several reasons try to explain the reason why people start to live on the streets, making a situation of exclusion from the conventional structures of society. The search for freedom, family maladjustment, dependence on alcohol and illicit drugs, the presence of mental illness, migration, unemployment, extreme poverty and amorous delusion are some of the reasons reported in the literature that cause people to seek the street as a place of residence $^{(9-10,13)}$. The overlapping of some of these reasons makes up the life trajectory of these people and joining the streets is almost never a personal option, but rather the lack of better alternatives.

Regarding the second category of analysis, "Diseases and health problems," the literature points out that the conditions and ways of life of the population living on the streets determine the health-disease process and care in a differentiated way and present different vulnerabilities to which this particular group is susceptible. A study that investigated the meanings and practices associated with the health-disease process of street people identified that the main health problems of this group were: psychoactive substance abuse, HIV/AIDS infection, mental disorders and problems odontological, dermatological and gastrointestinal. Health was associated with the capacity to withstand everyday difficulties while the disease was understood as a state of weakness that compromised the struggle for survival ${ }^{(14)}$.

Survey carried out in São Paulo-SP with hostel users showed that more than half of the interviewees considered their health as regular or poor and that health problems interfered with their daily activities ${ }^{(9)}$. Another study developed in a reception center with the objective of understanding the relationships existing in the process of re-signification of life on the street from a socially stigmatizing disease indicated that the diseases that affected the interviewees were HIV/AIDS, leprosy and the cancer. The lack of knowledge of the disease and the absence of a relative or other person to receive them, coupled with prejudice, have made these people believe in the proximity of death. Discrimination stemming from the stigma of diseases was pointed out as more frequent because they were in a street situation ${ }^{(12)}$.

Because it is a socially determined disease, tuberculosis affects the population living on the streets more frequently. It is observed the difficulty of adherence of this group to the treatment, which compromises the control of the disease, which is directly related to the living conditions of the people, resulting from social inequalities. Therefore, this reflects the state of poverty, the poor quality of the organization of the health system and the deficiencies of management, limiting the action of the technologies and, consequently, making difficult the control of diseases marked by the social inequality, showing the level of development in which is the country ${ }^{(15)}$. The care provided to people with tuberculosis and who are in a street situation is a challenge due to the difficulties in dealing with the reality of a deplorable social context and the inadequacy of services, as well as limitations involved in care ${ }^{(16)}$.

A survey conducted to describe the epidemiological profile, risk behaviors and frequency of syphilis in people living in the street context identified that $7 \%$ of the population studied had a diagnosis of this infection. Although there is knowledge available for diagnosis, treatment and cure, syphilis is considered a public health problem in this population as well. The authors pointed out the need to reinforce actions for their control through screening, diagnosis and early treatment strategies, with a view to reducing their occurrence in this vulnerable population ${ }^{(17)}$.

The articles referring to mental disorders in this population are related to obstacles to access to mental health services, attributed to the conditions of deprivation of rights and vulnerabilities faced, which hinder or delay the care and psychosocial rehabilitation. In addition, other barriers related to the work process of health professionals are highlighted, such as problems in the organization and initiative for active search work and difficulty in adequately hosting psychosocial care centers ${ }^{(18-19)}$. The street situation does not guarantee basic living conditions and, when coupled with daily suffering and lack of better perspectives, this situation can lead to loss of selfesteem and, consequently, a lack of concern for self-care ${ }^{(4)}$.

On the other hand, a study with people living in the street and suffering from socially stigmatizing diseases showed that the impact of the diagnosis provoked reflections on life, death and the need for care. Despite the extreme vulnerability that street life imposes and of harmful health habits, such as the abusive use of alcohol and other drugs and the greater 
exposure to violence from trafficking, once the person has learned that was suffering from a serious illness, her perception of the proximity of death led to changes in attitude and lifestyle. Thus, the study found that the interviewees overcame the disease impact stage and overcame the adversities they faced, bringing a new meaning to their lives ${ }^{(12)}$.

The analysis of the selected articles showed that several studies that addressed the issue of the health-disease process in a population living in a street situation pointed not only to the diseases to which this population is susceptible, but also to the health problems manifested by violence, chemical dependence, homicides, run-ins, among others.

The problem of abusive use of licit and illicit substances by the population living in a street situation is frequent. The consumption of psychoactive substances is often before the life on the street and this dependence accompanies the person because it is a way of being able to withstand the difficulties faced in the street ${ }^{(14)}$.

Violence is also a frequent grievance in the daily lives of these people. A study conducted in Salvador-BA revealed that this is a phenomenon of concern on the part of people who lived on the streets, especially at night. The fear of night-time attacks was reported by several respondents, who reported sleeping in a group or only during a time of clarity because they considered it safer ${ }^{(14)}$.

A research that sought to bring to the reflection the occurrence of violence in the life of women in a street situation showed that there is a relationship with drug use, insufficient income and rupture of family ties. The street was reported as the only alternative found to escape domestic violence. The main forms of violence mentioned in the literature were: physical and sexual violence, practiced by people who were intolerant of those who lived in the street, among the very people who were on the streets for a variety of reasons, such as territorial disputes, thefts , marital infidelity, disagreement and debts with traffickers. Another type of violence aimed at cleaning public spaces, being practiced by police or people hired by merchants and people who felt uncomfortable by the presence of this population. The authors argue that the complexity of the street situation for women points to the need to broaden the concept of care with a focus on interdisciplinarity and intersectoriality ${ }^{(13)}$.

Articles that refer to the third category, "Care practices and public policies" that support the health of the street population, discussed diverse topics.

One study reported the experience of the implementation of a project of the São Paulo City Department of Health, entitled "People on the street", which was implemented in seven basic health units in 2004. In this proposal, the team should provide assistance in the territory and act in an integrated way with other segments of the community to favor the channels of dialogue, creating links and shared commitments. This policy allowed the expansion of access to basic care services through specific work, work in the public places and reception centers, establishment of bond and integrality of care ${ }^{(2)}$.

Another article presented the experience of an event aimed at discussing the causality and complexity of the street population. The discussions were carried out in working groups, namely: networks of attention to the person in the street situation, assistance policies and devices for self-determination and public policies and intervention strategies. Several proposals have emerged for the topics addressed, such as: a network of articulation between the areas of health, education, sport, culture, environment and law; creation of shelters, vocational training programs, and income and literacy activities; promotion of social inclusion; inter-sectoral public policies, among others. The authors advocate that problems related to the street situation should be discussed by all sectors of society, since they are political, economic, cultural and social ${ }^{(20)}$.

A research that sought to understand the interface between public policies and the health care of the street population focused on a neglected disease, in the case of tuberculosis, pointed out that people living on the street with the disease form a stigmatized group and excluded that is marked by intense social suffering and also experience the duality between sanitary technical action and mechanisms of social isolation. In this sense, health work must incorporate the construction of a knowledge that understands the complexity of health issues and, thus, create unique strategies for each case based on the knowledge of the way of living on the street and health demands and needs specific group ${ }^{(21)}$.

A study that addressed the problems and barriers that presented in the integral care of populations in the street situation in the center of Rio de Janeiro-RJ brought important considerations. For example, despite the institution of the National Policy for Health Care of People Experiencing Street Situation, a delay in compliance with the principles and guidelines of said policy in the city was identified. Regarding the functioning of the health care network, it was pointed out the fragile intersectoriality between the policies and the poor integration between the services of the city, which prevented satisfactory care and the realization of social rights. Faced with this reality, challenges were imposed on managers and technicians to develop collective actions and seek work strategies that focus on the differences, relationships and potential of the subjects, giving them visibility ${ }^{(22)}$.

An integrative review that sought to identify issues related to the characterization of the street population, their needs and the existence of public policies pointed out that the debate on policies directed at street people is scarce. It is important to draw up social policies consistent with the needs of this population and to take into account the ethical principles recommended by the Unified Health System (SUS) ${ }^{(11)}$.

It is expected that the prejudice and stigma directed at the population living in the street situation will diminish, and that providing assistance to this population will no longer be the exclusive assignment of the office staff on the street, opening up directions of commitment to be built by all professionals ${ }^{(23)}$. For this, new approaches and restructuring of the work process in health care of this population are necessary, introducing formulations about the equity in access to health services ${ }^{(2)}$.

Although the Federal Constitution guarantees health as a right of citizenship and the duty of the State to be guaranteed through economic and social policies, there are several obstacles for people living in the street to access health services, such as difficulty in getting around, lack of perspective with 
the future, which compromises health care, the fear of suffering prejudice and stigma, and the lack of capacity of professionals to receive and provide care to this population. Despite the existence of a public policy aimed at this population, because it is a relatively recent policy, much still needs to be done to ensure access to care and health. The challenge of empowering health professionals to welcome the person in a street situation as a subject of law and bearer of a singular life trajectory and thus to meet their demands is highlighted. The dynamics of care must be understood, taking into account the needs imposed by street life, the establishment of links between the street staff and street people, and the overcoming of distancing due to social discrimination that hinders the accessibility of this street population to health services ${ }^{(24)}$.

Despite the advances made by public policies for street people, it is necessary to prevent the contradictions that occur in the state apparatuses themselves. It is necessary to walk in the production of bonds, in understanding the needs of these people and in the construction of alternative care and life outside the streets, whenever this is desired.

With regard to the fourth category of analysis, "Office on the street", several articles discussed the theme according to the importance of their actions. It is a care proposal that extends the accessibility and quality of care to the population living on the street and, in doing so, works in partnership with the basic health units and the Psychosocial Care Centers (CAPS). It is oriented to seek alternatives to the growing and complex demands present in the context of the street, by offering not only health care, but also the guarantee of rights as a citizen ${ }^{(24)}$.

It is known that people living on the street are one of the social groups that least access health services. However, this scenario has been modified with the institution of OSt, which seek to fully meet health needs and expand access to care, performing follow-up in the territory or in the health service ${ }^{(25)}$.

Studies on the offices on the street (OonS) related to the work process performed by the professionals of the street team. One of the analyzed articles emphasized that the professionals must share the responsibilities and define the strategies for the care of the people attended by the OonS and that the team work is fundamental for the practice in health with the population in situation of street, given the peculiarities and complexities present in this specific group ${ }^{(26)}$.

The reception and production of care carried out with the street population reveals that there is much to be done to implement the precepts defended in the public policies directed to this specific group. Therefore, the OonS seeks to guarantee the integral and quality care offered to this population, acting in addition to the therapeutic intervention, by valuing listening and welcoming as tools to recognize situations arising from street life, their particularities, the needs of health and the autonomy of people ${ }^{(24)}$.

Despite the advances achieved in the health care of the population living on the street, mainly from the institution of the OonS by the National Policy of Basic Attention, there are some impasses in the care directed to this population, such as the resistance of some health professionals in providing care due to stigmas, prejudices, discriminations and hygienist attitudes ${ }^{(23-24,26)}$.
A study carried out in Rio de Janeiro-RJ pointed out that bonding and qualified listening should not be exclusive to professionals who work with the population living on the street, but that the commitment to provide integral and quality care should extend to health professionals. It is noteworthy that the work carried out in a team, in an interdisciplinary way, made it possible to recognize the team as a reference for seeking care and, consequently, the constant stimulus for the team to rethink their work strategies and ways of acting directed to the reality of life of street people ${ }^{(23)}$.

The health practices developed by the OSt aim at the integral care of the people in the street situation and, for this, it is fundamental to build a bond between these actors, highlighting the dialogical relationship and the listening to be knowledge as indispensable. In addition to this, the health actions carried out in the daily work of the teams turn to the demands of the people in an articulated approach to the services of the basic health network and the intersectoral network. Thus, the work practices of the teams must understand that the reality in which they work involves a context of social inequality present in the daily life of this population, which, in addition to the precarious living conditions, carries the burden of invisibility as a human being ${ }^{(27)}$.

\section{Study limitations}

It is recognized that the inclusion of articles published only in national journals may have omitted important results from other countries, so it is considered a limitation of this study. In addition, the exclusion of articles that were not fully available on the Internet may be considered a second limitation of this research.

\section{Contributions to the area of nursing, health or public policy}

Emphasis is placed on the role of the nurse as a professional that compose the OSt, due to the importance of the establishment of a link to guarantee comprehensive health care for this population, according to their real health needs. In this sense, it is believed that the present study brings relevant contributions by giving visibility to the thematic and, thus, collaborate with the understanding of some aspects related to the health of the population that lives in the street situation and to help that both nurses and other professionals who provide assistance to this population can, based on the findings of this study, reflect on their health practices.

\section{CONCLUSION}

The analysis of the Brazilian scientific production about the people who make the street their dwelling having health as object of analysis points out that much still has to be done, such as the application of policies in an appropriate way, to guarantee the fulfillment of the demands and main necessities people living in the street.

In view of the situation presented, and recognizing the complexity of providing quality assistance to people living on the streets, the inclusion of the topic in the academic training of health graduates should be reinforced, so that they know and, in the future, incorporate this learning to their professional practices 
through teaching, research, extension and permanent professional education. It is necessary to invest in the formation of critical people, capable of acting in care in a way that is committed to the particularities of the ways of life and the health needs of the people in the street situation, and, in this way, to assure the fairness and integral attention to the health of that person specific group.

The relevance of the present study is believed, since it allowed visualizing the concern of the scientific community with the theme, evidenced by the increase in the number of works that have been developed over the last decade. The researches were connected to the social and political advances when reflecting on the importance of the specific public policies constructed for the people who experience the street situation, who assured, in the legal scope, a set of social rights, amplifying the conditions of access health services. At the same time, they discuss the challenges of ensuring integral health care and of constructing effective health care strategies considering the needs, demands and dignity of this population.

\section{REFERENCES}

1. Santana C. Outreach clinics on the street? reflections on new policies for homeless people's health. Cad Saúde Pública [Internet]. 2014 [cited 2017 May 12];30(8):1798-800. Available from: http://www.scielo.br/pdf/csp/v30n8/0102-311X-csp-30-8-1798.pdf

2. Carneiro-Jr NC, Jesus $\mathrm{CH}$, Crevelim MA. The family health strategy focused on access equity and targeted at the homeless population living in large urban centers. Saúde Soc [Internet]. 2010 [cited 2017 May 12];19(3):709-16. Available from: http:// www.scielo.br/pdf/sausoc/v19n3/21.pdf

3. Silveira C, Ribeiro MCSA, Carneiro-Jr N, Barata RB. Health social inequality of the homeless in the city of São Paulo. Saúde Soc [Internet]. 2015 [cited 2017 Jan 10];24(1):219-32. Available from: http://www.scielo.br/pdf/sausoc/v24s1/en_0104-1290-sausoc24-s1-00219.pdf

4. Brêtas ACP, Rosa AS, Cavicchioli GS. Cuidado de enfermagem ao adulto em situação de rua. In: Brêtas ACP, Gamba MA. Enfermagem e saúde do adulto. Barueri: Manole; 2006.

5. Brasil. Ministério da Saúde. Decreto nº 7.053 de dezembro de 2009. Política Nacional para a População em Situação de Rua; 2009.

6. Brasil. Ministério da Saúde. Portaria $\mathrm{n}^{0} 122$ de 25 de janeiro de 2011. Define as diretrizes de organização e funcionamento das equipes de Consultório na Rua. Diário Oficial da União;2012.

7. Mendes KDS, Silveira RCCP, Galvão CM. Integrative literature review: a research method to incorporate evidence in health care and nursing. Texto Contexto Enferm [Internet].2008 [cited 2017 Jan 10];17(4):758-64. Available from: http://www.scielo.br/pdf/ tce/v17n4/18.pdf

8. Bordignon JS, Silveira CCS, Delvivo EM, Araújo PP, Lasta LD, Weiller TH. Adultos em situação de rua: acesso aos serviços de saúde e constante busca pela ressocialização. Rev Contexto Saúde [Internet]. 2011 [cited 2016 Nov 23];10(20):629-34. Available from: https://www.revistas.unijui.edu.br/index.php/contextoesaude/article/view/1610/1349

9. Barata RB, Carneiro-Jr N, Ribeiro MCSA, Silveira C. Health social inequality of the homeless in the city of São Paulo. Saúde Soc [Internet]. 2015 [cited 2017 Jan 10];24(Supl-1):219-32. Available from: http://www.scielo.br/pdf/sausoc/v24s1/en_0104-1290sausoc-24-s1-00219.pdf

10. Andrade LP, Costa SL, Marquetti FC. The street has a magnet, I think it is freedom: power, suffering, and life strategies among homeless persons in the city of Santos, São Paulo, Brazil. Saúde Soc [Internet]. 2014 [cited 2017 Mar 10];23(4):1248-61. Available from: http://www.scielo.br/pdf/sausoc/v23n4/0104-1290-sausoc-23-4-1248.pdf

11. Paiva IKS, Lira CDG, Justino JMR, Miranda MGO, Saraiva AKM. Homeless people's right to health: reflections on the problems and components. Ciênc Saúde Colet[Internet]. 2016 [cited 2017 Jan 19];21(8):2595:606. Available from: http://www.scielo.br/pdf/ csc/v21n8/en_1413-8123-csc-21-08-2595.pdf

12. Antunes $\mathrm{CMC}$, Rosa AS, Brêtas ACP. From the stigmatizing disease to resignification of living on the streets. Rev Eletrôn Enferm [Internet]. 2016 [cited 2017 Jan 19];18:e1150. Available from: http://fi-admin.bvsalud.org/document/view/yx9jn

13. Rosa AS, Brêtas ACP. Violence in the lives of homeless women in the city of São Paulo, Brazil. Interface Comun Saúde Educ [Internet]. 2015 [cited 2017 Jan 19];19(53):275-85. Available from: http://www.scielo.br/pdf/icse/v19n53/en_1807-5762icse-19-53-0275.pdf

14. Aguiar MM, Iriart JAB. Meanings and practices associated with health and illness among the homeless in Salvador, Bahia State, Brazil. Cad Saúde Pública [Internet]. 2012 [cited 2017 Jan 19];28(1):115-24. Available from: http://www.scielo.br/pdf/csp/ v28n1/12.pdf

15. Souza ES, Zioni F. O tratamento diretamente observado para a tuberculose entre a população em situação de rua. In: Rosa AS, Brêtas ACP. Enfermagem e saúde: olhares sobre a situação de rua. Curitiba: CRV; 2013.

16. Alecrim TFA, Mitano F, Reis AA, Roos CM, Palha PF, Protti-Zanatta ST. Experience of health professionals in care of the homeless population with tuberculosis. Rev Esc Enferm USP [Internet]. 2016 [cited 2017 Jan 19];50(5):809-16. Available from: http://www. scielo.br/pdf/reeusp/v50n5/0080-6234-reeusp-50-05-0809.pdf 
17. Pinto VM, Tancredi MV, Alencar HDR, Camolesi E, Holcman MM, Grecco JP, et al. Prevalence of Syphilis and associated factors in homeless people of Sao Paulo, Brazil, using a Rapid Test. Rev Bras Epidemiol [Internet]. 2014 [cited 2017 Jan 19];17(2):341-54. Available from: http://www.scielo.br/pdf/rbepid/v17n2/1415-790X-rbepid-17-02-00341.pdf

18. Borysow IC, Furtado JP. Access, equity and social cohesion: evaluation of intersectoral strategies for people experiencing homelessness. Rev Esc Enferm USP [Internet]. 2014 [cited 2017 Jan 25];48(6):1069-76. Available from: http://www.scielo.br/pdf/ reeusp/v48n6/0080-6234-reeusp-48-06-1069.pdf

19. Borysow IC, Furtado JP. Acesso e intersetorialidade: o acompanhamento de pessoas em situação de rua com transtorno mental grave. Physis [Internet].2013 [cited 2016 Nov 23];23(1):33-50. Available from: http://www.scielo.br/pdf/physis/v23n1/03.pdf

20. Fiorati RC, Carretta RYD, Panúncio-Pinto MP, Lobato BC, Kebbe LM. Population in vulnerability, inter-sector cooperation and citizenship: interconnecting knowledge and actions. Saúde Soc [Internet]. 2014 [cited 2017 Jan 25];23(4):1458-70. Available from: http://www.scielo.br/pdf/sausoc/v23n4/0104-1290-sausoc-23-4-1458.pdf

21. Adorno RCF. Atenção à saúde, direitos e diagnóstico como ameaça: políticas públicas e as populações em situação de rua. Etnográfica [Internet].2011 [cited 2017 Jan 22];15(3):543-67. Available from: http://journals.openedition.org/etnografica/1068

22. Serafino I, Luz LCX. Políticas para a população adulta em situação de rua: questões para debate. Rev Katál [Internet].2015 [cited 2017 Jan 25];18(1):74-85. Available from: http://www.scielo.br/pdf/rk/v18n1/1414-4980-rk-18-01-00074.pdf

23. Silva CC, Cruz MM, Vargas EP. Care practices and homeless population: the street clinic case. Saúde Debate [Internet]. 2015 [cited 2017 Jan 25];39(Esp):246-56. Available from: http://www.scielo.br/pdf/sdeb/v39nspe/0103-1104-sdeb-39-spe-00246.pdf

24. Hallais JAS, Barros NF. Street Outreach Offices: visibility, invisibility, and enhanced visibility. Cad Saúde Pública [Internet]. 2015 [cited 2017 Jan 25];31(7):1497-504. Available from: http://www.scielo.br/pdf/csp/v31n7/0102-311X-csp-31-7-1497.pdf

25. Macerata I, Soares JGN, Ramos JFC. Apoio como cuidado de territórios existenciais: atenção básica e a rua. Interface comum saúde educ [Internet].2014 [citado 2017 Jan 10];18(Suppl-1):919-30. Available from: http://www.scielo.br/pdf/icse/v18s1/18075762-icse-18-1-0919.pdf

26. Kami MTM, Larocca LM, Chaves MMN, Piosiadlo LCM, Albuquerque GS. Tool and ideological knowledge in Street Outreach Office working process. Rev Esc Enferm USP [Internet]. 2016 [cited 2017 Jan 25];50(3):442-9. Available from: http://www.scielo. $\mathrm{br} / \mathrm{pdf} / \mathrm{reeusp} / \mathrm{v} 50 \mathrm{n} 3 / 0080-6234-$ reeusp-50-03-0442.pdf

27. Silva FP, Frazão IS, Linhares FMP. Health practices by teams from Street Outreach Offices. Cad Saúde Pública [Internet].2014 [cited 2016 Nov 15];30(4):805-14. Available from: http://www.scielo.br/pdf/csp/v30n4/0102-311X-csp-30-4-0805.pdf 